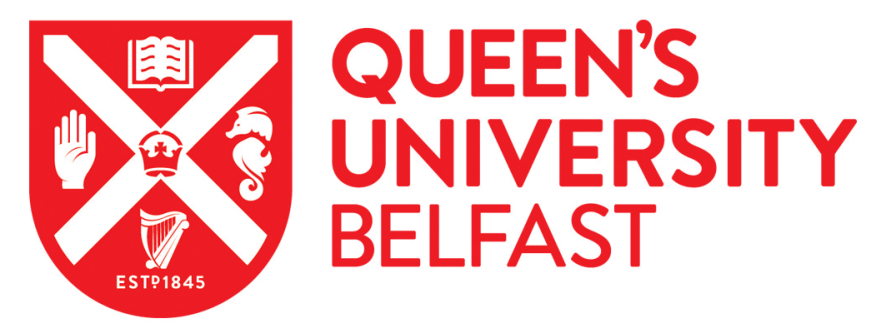

\title{
How do patients experience caring? Scoping review
}

Gillespie, H., Kelly, M., Duggan, S., \& Dornan, T. (2017). How do patients experience caring? Scoping review. Patient Education and Counseling, 100(9), 1622-1633. https://doi.org/10.1016/j.pec.2017.03.029

\author{
Published in: \\ Patient Education and Counseling
}

Document Version:

Peer reviewed version

Queen's University Belfast - Research Portal:

Link to publication record in Queen's University Belfast Research Portal

\section{Publisher rights}

(c) 2017 Elsevier Ltd. This manuscript version is made available under the CC-BY-NC-ND 4.0 license http://creativecommons.org/licenses/by$\mathrm{nc}-\mathrm{nd} / 4.0 /$,which permits distribution and reproduction for non-commercial purposes, provided the author and source are cited.

\section{General rights}

Copyright for the publications made accessible via the Queen's University Belfast Research Portal is retained by the author(s) and / or other copyright owners and it is a condition of accessing these publications that users recognise and abide by the legal requirements associated with these rights.

Take down policy

The Research Portal is Queen's institutional repository that provides access to Queen's research output. Every effort has been made to ensure that content in the Research Portal does not infringe any person's rights, or applicable UK laws. If you discover content in the Research Portal that you believe breaches copyright or violates any law, please contact openaccess@qub.ac.uk. 


\section{How do patients experience caring? Scoping review}

2

3 Hannah Gillespie ${ }^{a}$, Martina Kelly ${ }^{b}$, Sarah Duggan ${ }^{a}$, Tim Dornan $^{a}$

4

$5 \quad{ }^{a}$ Centre for Medical Education, Faculty of Medicine, Health, and Life Sciences, Queen's University Belfast, Belfast, UK

$6 \quad{ }^{b}$ Department of Family Medicine, Cumming School of Medicine, University of Calgary, Calgary, Canada

8 Corresponding author:

9 Tim Dornan

10 Centre for Medical Education,

11 Whitla Medical Building,

1297 Lisburn Rd,

13 Belfast

14 BT9 7BL,

15 UK

16

17 Tel: +442890975773

18 Fax: +4428 90972322

19

20

timothy.dornan@gmail.com 


\section{Abstract}

\section{Objective}

Summarise empirical research into patients' experiences of caring in order to promote this as a core condition for the work of health professionals. Methods A review team: carried out a scoping review with a phenomenological orientation that did not privilege any profession or context of care; comprehensively searched six databases from inception to the present, including all English language articles that report patients' lived experiences of caring; and identified and contrasted uncaring experiences.

\section{Results}

3343 articles straddled nursing, medicine, and physiotherapy, and a wide range of care settings. 34 Patients experienced caring when competent professionals displayed positive attitudes, communicated effectively, formed relationships, helped them navigate clinical services, and engaged emotionally.

\section{Conclusion}

This research provides a rich description of caring, which was derived from patients', rather than professionals', experiences.

\section{Practice Implications}

41 Whilst publications and basic professional curricula are dominated by the perspectives of single

42 professions, this research describes patients' experiences that can prepare all health professionals to be caring in collaborative, interprofessional practice. 
'The essence of the practice of medicine is that it is an intensively personal matter.'

Francis Peabody 1927 [1]

\section{Introduction}

The work of health professionals 'touches our lives at times of basic human need, when care and compassion are what matter most'. [2] Despite caring being central to clinical practice, it is easier to say it is absent [3] than to say what it is. Caring is a core value of the nursing profession. [4] Peabody famously said caring is core to medicine too [1] and this has been reaffirmed. [5] But technical progress since Peabody's time has widened the concept of caring to mean much more than humane behaviour. [6] The number of professions that contribute to interdisciplinary teamwork has increased too, introducing new perspectives on caring. There has been a drive to teach clinical communication, and define and assess professionalism. Whilst this parsing into components has made it easier to teach and assess aspects of caring, it has not made the essence of caring any clearer. And patients have not usually been involved in clarifying what it is. Finding out what caring means to those who benefit from it would help interprofessional practitioners meet patients' human needs and teach students to do the same. This would reinvigorate the core value of patient care.

Contemporary arguments, as well as historical ones, mandate research into caring. Licensing bodies censure doctors who do not 'make the care of your (sic) patient your first concern'. [6] Politicians condemn healthcare systems for providing 'appalling care'. [3] Caring guides curriculum design. [5] Such an everyday word as caring helps lay people enter discussions about professional standards. And its breadth of meaning encompasses values, individual behaviours, and systemic processes. This advantages caring over more specific and technical terms like 'presence', 'compassion', 'empathy', and 'relationship' because it embraces all of them. The word caring sets fuzzy boundaries within which a holistic concept of clinical humanism can take shape. But licensing bodies are not satisfied with fuzzy boundaries. This poses what Schön [7] identified as a central problem of professional education: the 'Meno Paradox'. In a dialogue with Socrates about virtue, his disciple Meno became so frustrated by being unable to define wisdom that he burst out: 'How on earth are you going to set up something you don't know as the object of your search?'.

One way of resolving the paradox would be to reach consensus on a definition of caring. Authors have, however, disagreed whether that is worth doing. On one hand, defining caring has been described as 'approximately 350 years out of date' [8]; on the other, researchers have continued to define it. [9] They have usually done so within specific professions or care settings, which limits the applicability of their work. The idea that caring means different things to doctors and nurses is long established. [1] Nurses have laid claim to caring as the essence of their profession $[4,10,11]$ and nursing journals regularly publish primary and secondary research on the topic (for example $[4,12-$ 
14]). As well as in medicine and nursing, caring has been researched in physiotherapy $[15,16]$ and interprofessional team working. [9] But when the concept of caring has been made more general by widening the disciplinary mix, it has been made more specific by concentrating on specific clinical settings. These include: palliative care, [9] acute internal medicine, [17] primary care, [18] oncology, [19] and the management of irritable bowel syndrome [20] and substance abuse. [21] Curriculum leaders are in a bind. Regulators require them to graduate caring, pluripotent, interprofessional health workers, yet professionals have only been able to define caring in specific professions or care contexts, if at all.

Socrates would have been unsurprised that professionals have not been able to define caring any better than he could have defined virtue. Perhaps patients could define caring better? As judged by empirical research, however, clinicians, educators, and researchers have been readier to speak on behalf of patients than give them a voice. For example, four of 11 scales that implicitly define caring by measuring patients' experiences of it [22] are rated by professionals (usually nurses) rather than patients. It is unclear how the other seven caring measurement scales reflect patients' self-identified needs. There are, however, early signs that professionals will allow patients to say what caring is. A theory-building review of how 35 articles defined caring [11] found that an important minority were shifting the field from nurse-focused to patient-focused conceptualisations. Four articles identified patients' experiences of caring and eight treated patients as authorities who should define caring. This uncovered a discrepancy between what patients and nurses found important [11,23-25], which shows how important it is to understand caring as experienced by patients themselves and not to conflate that with professionals' experiences. This overview suggests that the quest for a definition of caring may, indeed, [11] be a fruitless one.

A Socratic alternative to resolving the Meno Paradox by defining caring would be to acknowledge that caring is indefinable and report, in all their richness, patients' experiences of it. To that end, researchers have examined theory $[4,11]$ and synthesised empirical evidence [13,14,26-28]. They have come at this from several angles: caring $[4,11,13,14]$, patient-centredness, [29] doctor-patient relationships, [26] and systems of care. [27] Empirical reviews have not usually had conceptual frameworks though phenomenology guided one theory-building review. [4] This corpus of work, however, had the same limitation as primary research. It was conducted within specific disciplines usually medicine $[26]$ or nursing $[4,11,13,14]$ - or in specific clinical contexts.

What is lacking is a synthesis of patients' experiences of caring that draws from more than a single profession and/or clinical context and has a conceptual orientation. Our aim was to summarise empirical research into patients' experiences in order to promote caring as a core condition for the work of health professionals. 


\subsection{Conceptual Orientation}

114 Our intention to explore the essence of caring by synthesising patients' accounts of their experiences of it led us to take a phenomenological stance. This conceptual orientation is rooted in the work of early twentieth century philosopher Edmund Husserl. [30] Phenomenology is relevant to this research because it combines a theory of being in the world, which acknowledges our interest in the lived experience of being cared for, with a theory of knowledge, which acknowledges our interest in how patients speak about those experiences. Phenomenology is, typically, applied to primary research. Ours was, in contrast, secondary research, reviewing data derived from mostly non-phenomenological research. So our research was phenomenological in so far as this theory provided an ontological and epistemological justification for our approach and a method of analysis. Phenomenologically speaking, the word caring describes 'a state of being', patients' experience of which is of interest.

\subsection{Research team}

The research was conducted in Canada and Northern Ireland, UK. Two medical students and two physicians, who are also education researchers (a family physician and an internist/ endocrinologist), formed the research team. The medical students had received interprofessional education and both physicians have extensive experience of interprofessional practice.

\subsection{Procedural steps}

Scoping review is a methodology well-suited to a complex topic like caring because it can map key concepts, types of available evidence, and gaps. We followed the five step approach devised by Arksey and O'Malley [31] as revised by Levac and colleagues. [32]

Our starting assumption, justified earlier, was that caring is a fuzzy concept that cannot be defined but exists in patients' experiences. We met personally, conferenced via the Internet, corresponded by email, and discussed the results of a pilot search. Throughout this and the following stages, we followed the phenomenological process of discussing our preconceptions and biases in order to attend to the essence of patients' experiences rather than our own. We defined 'a patient' as any individual receiving any form of healthcare delivered by any healthcare professional (HCP) in any setting. This mandated a broad search, including an unlimited range of types of patients and healthcare providers. The wording of our review question was: "What is known from existing publications about the qualities, attributes, and behaviours of healthcare professionals that patients 
A librarian helped devise a preliminary search. This was piloted in MEDLINE, refined, and tailored to search across six databases. Table 1 shows how searching and selecting evidence complied with 'STARLITE' criteria. [33] We devised a search syntax by separating the research question into its component parts. MeSH-terms and text-words for care (empathy, sympathy, altruism, compassion, trust, kindness, social behaviour), experience (perception) and healthcare occupation (doctor, nurse, midwife, counsellor, therapist, pharmacist, occupational therapist, healthcare personnel) were combined to perform the search and adapted for each database. When databases produced over 2000 results, we limited the search to article titles. We decided to exclude non-English language articles because nuanced language might be lost in translation. Although we were searching for evidence that was explicitly about caring, there were articles about relationships that, on careful reading, were about caring relationships and therefore implicitly about caring. Since reflexive interaction between researchers and the materials they are working with is integral to phenomenological analysis, we included these articles.

Before definitively selecting articles, we conducted a calibration exercise to evaluate and increase the reliability of article selection. This entailed two authors independently screening a random $10 \%$ sample of articles. A second exercise entailed two authors (HG and TD) reviewing the abstracts of articles identified in a pilot search and a third author (MK) resolving discrepancies in their application of the inclusion criteria. Fig 1 uses the PRISMA convention to show the selection stages. [34] We developed, applied, and refined the inclusion and exclusion criteria shown in Table 2 as we became more familiar with the nature of the evidence.

Thirty-six articles identified by searching and a further seven identified by screening reference lists directly described patients' experiences of how healthcare providers affected them. These included primary and secondary studies using qualitative, quantitative, and mixed-methods designs. Although not mandatory for scoping reviews, the Critical Appraisal Skills Program (CASP) toolkit [35] and a simple 5-point scale described elsewhere [36] helped evaluate articles' trustworthiness. This was not to exclude articles but to give them proportionate weight in the synthesis.

A concern that positive publication bias might have reduced the number of included articles led us to repeat the search using 'uncaring' as the key search term. This identified one hundred and ninety titles, of which seven matched our inclusion criteria. Review of these articles confirmed, but did not add to, the results presented below. We did not include them in the results section since 'caring', rather than 'uncaring', was the topic of our research. 
We created a data extraction sheet using Microsoft Excel (Microsoft, Redmond, USA), piloted it on a small set of the studies, and refined it. The final form included demographic details, methodological details, and patients' descriptions of caring (or uncaring) experiences. To maintain the phenomenological emphasis, we extracted all relevant data from each paper in a way that would complete the sentence: "This research shows that a patient experienced caring as ...". In order to achieve consensus about data extraction processes, three members of the research team (HG, SD, TD) independently extracted relevant data from a subset of the included articles and discussed their findings. One author (HG) read and extracted the remaining data items, which totaled 1011 rows in the spreadsheet.

\subsubsection{Collating, summarising and reporting results}

Given the heterogeneity of studies and outcomes reported, we used a narrative approach to collate, summarize, and map data. Most articles reported positive experiences of care. Negative experiences were too few to support separate analysis and mirrored positive ones. Since our intention was to identify dimensions of caring rather than position patients' experiences along those dimensions, we reworded negative experiences positively; for example, '... a nurse not listening to me' became '... a nurse listening to me'. We reviewed the dataset, discussed our interpretations, and developed a coding framework with six main themes. HG maintained an audit trail of procedures, team meetings, and analytical decisions. As we clustered items into well-defined categories and synthesised an interpretation, we chose labels that stayed as close as possible to the words patients used to describe caring experiences. For brevity and to minimise repetition, we have sometimes abbreviated the phrase 'was experienced as caring' to 'was caring'. Peer-review identified epistemological tensions so we focused the 'voice' of the article more clearly and consistently on patients' lived experiences

\section{Results}

Table 3 shows that the final set of articles, which represented the views of over 1,000 patients aged 19 - 91 years, spanned a range of clinical contexts and geographical locations. Patients experienced a heterogeneous group of qualities, attributes, and behaviours as caring. An individual HCP did not necessarily demonstrate all these; rather, there was a complex interplay between what individual HCPs demonstrated, and individual patients experienced as caring. Specifically, patients experienced:

1. Competence

2. Positive attitudes

3. Effective communication 
4. Relationships

5. Being helped to navigate clinical services

6. Emotional engagement

Table 4 summarises these findings, referring to source publications and presenting illustrative quotations. We now present the findings in more detail.

\subsection{Competence}

Patients experienced caring when HCPs applied requisite knowledge and skills in a deliberate and determined manner; when they made diagnoses correctly and managed patients' symptoms appropriately; when they did more than prescribe medication; when they thought and acted beyond patients' immediate symptoms, and treated underlying causes of illnesses. Patients experienced caring when HCPs combined technical competence and experiential knowledge. Patients recognised, however, that HCPs were not infallible. Recognising mistakes, apologising, and making efforts to rectify them was experienced as caring. The net effect was for patients' to experience their needs as proficiently met.

\subsection{Caring HCPs displayed positive attitudes}

Patients experienced caring when professionals displayed positive attitudes: when they were sincere, thoughtful, sensitive, and friendly to patients and colleagues. Patients experienced caring when HCPs were appropriately positive and optimistic, approachable, and understanding, displayed commitment and enthusiasm, expressed supportive emotions (empathy, compassion, and sympathy), and were sensitive to patients' needs and wishes. When HCPs were supportive, understanding, and respectful, patients' experienced caring. Being reliable and trustworthy was experienced as caring, as was acting with sincerity, honesty and respect. Being patient and working in a calm, yet confident, manner; being attentive, efficient, and vigilant; being encouraging, supportive, and helpful; and being cheery, good humoured, and polite were all experienced as caring. Not being judgmental, patronising or condescending was caring. Patients experienced caring when professionals were genuine.

\subsection{Effective communication}

Caring communication extended beyond dialogues between doctors and patients to communication within teams and with other professional disciplines. Caring communication could be subdivided into four categories. 
Patients experienced caring when HCPs chose their words carefully, made helpful comments that responded to patients' needs, and answered questions; when HCPs were forthright and straightforward but not abrupt. Caring was feeling that your illness had been acknowledged because information was given in clear and sensitive ways, which balanced honesty and tact. Having questions answered empathically and respectfully, receiving thorough explanations with measured amounts of information, not being subjected to medical jargon, and not being patronised were caring.

\subsubsection{Listening}

Patients experienced caring when HCPs spent time listening to them. This created an open space in which patients could express concerns and ask questions without being interrupted. Caring was interest being shown in what patients said. It was being actively listened to, responded to meaningfully, and actions being taken. It was an HCP listening to and understanding patients' views. It was having their concerns taken seriously and their experiences not belittled.

\subsubsection{Non-Verbal Behaviour}

Various non-verbal behaviours were experienced as caring: appropriate body language, eyecontact, and smiling. Caring was not feeling threatened because HCPs appeared to be comfortable during consultations and touched patients sensitively. This silent language established a sense of mutual understanding.

\subsubsection{Sharing Knowledge}

Caring was being offered explanations and information periodically or continuously according to patients' individual wishes. It was sharing in clinicians' experiential knowledge and being told what to expect. It was being advised, not being dictated to. It was involvement in decisions and experiencing a sense of partnership. It was HCPs acknowledging patients' expertise about themselves and their illnesses, and showing interest in their opinions. It was receiving verbal and written information, and being directed towards additional sources of information.

\subsection{Relationships}

Patients experienced caring within meaningful relationships that made them feel comfortable and at ease. Caring relationships 'connected' patients with HCPs. Such relationships gave patients an experience of HCPs understanding their illnesses and how these affected their lives and activities. Patients experienced similarities between caring relationships with HCPs and relationships with family members and friends. 
Caring relationships gave an experience of mutual trust and respect, and being valued. This trust created partnership between HCPs and patients, and sometimes with patients' families or lay carers. Patients experienced HCPs accompanying them on their 'journeys' and getting to know them and their illnesses better as caring.

\subsubsection{Patients as individuals}

Caring was the experience of being at the centre of a relationship with an HCP. It was being treated as an individual rather than a disease entity. It was an HCP acknowledging and respecting that one patient had different wishes from another patient. It was receiving personalised information and support. It was account being taken of patients' personal values and clinical care being integrated into their individual circumstances.

\subsection{Being helped to navigate clinical services}

Patients experienced caring when HCPs ensured that clinical processes were efficient, prompt, reliable, holistic, and responsive to patients' needs.

\subsubsection{Caring was internally motivated}

Caring was experiencing HCPs as genuinely wanting to help; being supportive, guiding, and encouraging. It was feeling that an HCP had taken trouble to make referrals to other services or for religious or spiritual support. It was a sense that HCPs were motivated by a genuine desire to help rather than status or pay. It was experiencing an excellent service, which went above and beyond expectations. It was experiencing privacy and dignity.

\subsubsection{Caring was continuing}

Continuity of care, preferably within one-to-one relationships that persisted over time, was experienced as caring. This temporal relationship provided more than just treatment and monitoring; it fostered trust. Caring was experiencing continuity between different HCPs and different teams. It was experiencing HCPs collaborating and communicating with one another and involving members of clinical disciplines other than their own when needed. Caring was being helped to navigate transitions between primary and secondary care.

\subsubsection{Caring included patients}

Patients experienced caring when HCPs encouraged them to be active participants in their own care, share in decision-making, and arrive at shared goals. Caring was being given control, independence, and choice, whilst knowing that advocacy was at hand when required. 


\subsection{Emotional engagement}

311 Caring was experiencing HCPs as emotionally engaged, accessible, and easily contactable. It was not being made to feel rushed and feeling good use was being made of time. It was the experience of an HCP taking the initiative to contact or visit a patient. Caring was being made to feel safe, secure, and able to relax in clinical environments. It was feeling protected from harm by the presence of an HCP. It was feeling empowered, enabled, and encouraged to take control of one's illnesses and treatments.

\section{Discussion and Conclusion}

\subsection{Discussion}

4.1.1 Principal findings and relationship to earlier publications

The findings of this study are encapsulated by the aphorism that 'whilst the treatment of a disease may be entirely impersonal, the care of a patient must be completely personal'. [1] Patients experienced caring when HCPs tailored a range of relational and organisational skills, values, and behaviours to their personal needs and preferences. Attributes that contributed to this experience included being appropriately skilled and knowledgeable, maintaining continuity, and being prompt, efficient, reliable, accessible, and seemingly unhurried. Less tangible, yet still powerfully experienced, were values and emotions that underpinned those behaviours. These included being concerned for others, being intrinsically motivated, and being humble. Admitting fallibility and apologising when things went wrong gave rise to such experiences as did a variety of often small actions that engendered the mutual trust, respect, and safety that lay at the heart of therapeutic relationships. Patients experienced caring HCPs as genuine. They knew this when they experienced it, but genuineness defied a simple behavioural definition.

A value and behaviour that runs through the findings and deserves special mention is reciprocity. Patients experienced caring within the dynamics of consultations that gave patients the independence and choice they wanted and needed to navigate systems of care. Caring was listening and conversing with rather than communicating to. Skill was necessary for this but not sufficient; sharing control called for genuine respect towards others.

A strength of this research was to take the phenomenological assumption that patients' needs and experiences should be the central preoccupation of healthcare as the starting point for a scoping review. This allowed the findings to transcend professional assumptions about what is good for patients, and crossed the boundaries of individual professions, specific contexts, and systems of care. It uncovered the intimate link between competence and caring. 
The findings agree with earlier secondary research into patients' experiences [13,14,26,27], which has defined caring as displaying appropriate professional behaviours, being competent, being present, forming relationships, communicating well, and managing services. Most publications included just one or two of our dimensions and none included all six. It is a matter of opinion whether, for example, communication is better served by separating it from the broader construct of caring. Suffice it to say that this research provides a rich description of caring, with a central focus on patients' experiences and reciprocity with professionals.

\subsubsection{Limitations}

An important limitation is that all clinical members of the team were students or practitioners of medicine. This reflects the current state of health professions education where practice is mostly interprofessional but basic education is mostly uniprofessional. Whilst we synthesized evidence from any profession that has researched caring, our disciplinary perspective best equipped us to inform the uniprofessional or interprofessional education of doctors. Other professions and all contexts of medical care might, nevertheless, find it informative. Another limitation was dominance of the evidence by nursing publications. There was also an apparent generosity bias in that more publications reported caring than uncaring behaviour. The limited number of negative reports, arguably, led us to accentuate that bias by rewording negative experiences in positive words. Our intent, though, was to define dimensions along which patients' experiences may be negative as well as positive. Another limitation is that we did not question patients' authority to define caring and reported only their experiences, not HCPs'. This limitation applies, particularly, to behaviours that require professional training to judge. Clinical competence is an important case in point. This raises the troubling question of when it is better to be brusque and have no mistakes to apologise for, and when caring equates with recognising one's mistakes, apologizing, and trying to rectify them. Likewise, reassuring a patient that all is well is less caring than explaining the distinctly un-reassuring fact that a scan shows extensive liver metastases. Competence and caring are not at odds with one another but patients' ability to judge those aspects of competence that can only be judged objectively is inevitably less than than their ability to experience social aspects of caring.

Our findings risk idealising caring without acknowledging that busy and under-resourced care settings may constrain it. No health worker can reasonably be expected to care ideally in every possible regard so our counter-argument is that defining a set of dimensions allows positive behaviour along one - striving to be attentive and pleasant, for example - to offset another - having little time available. 
377

378

379

380

381

382

383

384

385

386

387

388

389

390

391

392

393

394

395

396

397

398

399

400

401

402

403

404

405

406

407

408

409

To rewrite dictionary definitions of caring would be simplistic and impractical. Instead, we have provided a rich description of factors, which influence whether or not patients experience caring. Whilst the evidence is limited compared with the numerous descriptions and definitions of caring provided by professionals, it has intrinsic moral authority and suggests numerous ways HCPs can make patients' experiences of clinical encounters more or less positive. Simple practical behaviours lead to caring experiences. These are often neglected in the erudite climate of universities yet clinicians can easily model them and help learners display them. Caring comprises many attributes, values, and behaviours. Different practitioners have different quantities and qualities of them and none, alone, is sufficient. The essence of caring is to combine them in a way that meets an individual patient's needs at a particular moment.

\subsection{Practice Implications}

Educational practice was the main target of this research. Caring can only be a core value of health professional practice if it is reinforced in the basic, early postgraduate, and continuing phases of lifelong health professions education. Because experienced practitioners and novices work together, education can be mutually reinforcing if all phases are included, or doomed to failure if they are not. So, education for caring has to be systemic. Moreover, contemporary health care systems are interprofessional so education has to shift from its traditional, uniprofessional focus.

The first practice implication is that we have provided a rich description of caring that is applicable to contemporary, interprofessional curricula for practitioners at all levels of experience. Its validity comes from focusing on the central focus of attention of all professionals - patients - and piecing together commonalities between individual professions. This helps curriculum leaders out of the awkward situation of being expected to graduate caring, pluripotent, interprofessional health workers when care could hitherto only be defined in specific professions or care contexts. Its validity rests on first exploring what attributes it would be desirable for graduates to show and then deriving educational implications rather than the more usual reverse.

A second implication is that the set of interrelated values and observable behaviours described here can be modeled by practitioners and assessed in formative and summative assessments.

A third one is that our account challenges the dichotomy between competence and caring. Both are important but neither alone is sufficient. We have resolved interprofessional differences of emphasis that strengthen a false dichotomy between the two.

A fourth implication is that our account of caring promotes reciprocity between patients and practitioners. The pressured conditions in which practitioners deliver contemporary healthcare 
410 challenge their values and lead to stress and burnout. Reciprocity could keep their values alive and serve as an antidote to stress.

412 The fifth and arguably most important implication is that small, simple things make big differences to patients' experiences. Rather than adding new layers of complexity to health

414 professions education, our findings suggest that practitioners are caring when they allow their basic 415 humanity to bring their professional attributes into alignment with individual patients' needs. To 416 foster caring, teachers and practitioners should emphasize the individual, genuine, and often 417 momentary nature of care.

418 The final implication is that caring has many dimensions, at least some of which reside in 419 patients' lived experiences, defy definition, and can only be experienced - not taught. We have not 420 resolved the Meno Paradox. Like virtue, learning to be caring is a career-long journey that leads each 421 individual HCP to a distinctly personal destination. Therein lies the attraction and reward of working 422 in a caring profession.

\section{Acknowledgments}

426 We thank Ms Heather Ganshorn for helping construct and run the searches, the late Professor Karen

427 Mann for reviewing the manuscript, and Professor Gerry Gormley for encouragement throughout the project.

Funding

431 This research did not receive any specific grant from funding agencies in the public, commercial, or not-for-profit sectors. 
435 [1] F.W. Peabody, The Care of the Patient, JAMA - J. Am. Med. Assoc. 88 (1927) 877-882.

436 [2] NHS Choices, NHS Constitution, (2013).

437 [3] R. Francis, Report of the Mid Staffordshire NHS Foundation Trust Public Inquiry, 2013. doi:10.1002/yd.20044.

[4] K. Swanson, Empirical development of a middle range theory of caring, Nurs. Res. 40 (1991) 16-66.

[5] D. Balmer, D. Hirsh, D. Monie, H. Weil, B.F. Richards, Caring to Care, Acad. Med. (2016) 1. doi:10.1097/ACM.0000000000001207.

[6] Good Medical Practice: Working with doctors working for patients, (2013). doi:10.1016/B9780-7020-3085-7.00001-8.

[7] Schön DA, Educating the Reflective Practitioner: Towards a New Design for Teaching and Learning in the Professions. 1990. San Francisco : Jossey-Bass.

[8] J. Paley, An archaeology of caring knowledge, J Adv Nurs. 36 (2001) 188-98. doi:10.1046/j.1365-2648.2001.01959.x.

[9] Q. Guo, An Evolutionary Concept Analysis of Palliative Care, J. Palliat. Care Med. 2 (2012). doi:10.4172/2165-7386.1000127.

[10] J. Watson, Nursing: The Philosophy and Science and Caring, Caring Nurs. Class. An Essent. Resour. (2012) 143-52.

[11] J.M. Morse, S.M. Solberg, W.L. Neander, J.L. Bottorff, J.L. Johnson, Concepts of caring and caring as a concept, ANS. Adv. Nurs. Sci. 13 (1990) 1-14.

http://www.scopus.com/inward/record.url?eid=2-s2.00025485043\&partnerID=40\&md5=1ca1c09f504e6074f4c4d25caab1e0a3.

[12] B. Andershed, K. Olsson, Review of research related to Kristen Swanson's middle-range theory of caring, Scand. J. Caring Sci. 23 (2009) 598-610. doi:10.1111/j.14716712.2008.00647.x.

[13] D. Finfgeld-Connett, Meta-synthesis of caring in nursing, J. Clin. Nurs. 17 (2008) 196-204. doi:10.1111/j.1365-2702.2006.01824.x.

[14] G. Sherwood, Meta-synthesis of qualitative analyses of caring: defining a therapeutic model of nursing, in: M. Smith, M. Turkel, Z.R. Wolf (Eds.), Caring Nurs. Class. an Essent. Resour., Springer New York, New York, 2013: pp. 257-70.

[15] M.E. Del Bano-Aledo, F. Medina-Mirapeix, P. Escolar-Reina, J. Montilla-Herrador, S.M. Collins, Relevant patient perceptions and experiences for evaluating quality of interaction with physiotherapists during outpatient rehabilitation: a qualitative study., Physiotherapy. 100 (2014) 73-79. http://ovidsp.ovid.com/ovidweb.cgi?T=JS\&PAGE=reference \&D=medI\&NEWS=N\&AN=237782 64.

[16] B. Greenfield, E. Keough, S. Linn, D. Little, C. Portela, The meaning of caring from the perspectives of patients undergoing physical therapy: A pilot study, J. Allied Health. 39 (2010) 43-48.

[17] M. Attree, Patients' and relatives' experiences and perspectives of 'Good' and 'Not so Good' quality care, J. Adv. Nurs. 33 (2001) 456-466. doi:10.1046/j.1365-2648.2001.01689.x.

[18] V. Copeland, S. Scholle, J. Binko, Patient satisfaction: African American women's views of the patient-doctor relationship, J. Heal. Soc. Policy. 17 (2003) 35-48. doi:10.1300/J045v17n02.

[19] J. Lafferty, F. Rankin, C. Duffy, P. Kearney, E. Doherty, M. McMenamin, V. Coates, Continuity of care for women with breast cancer: A survey of the views and experiences of patients, carers and health care professionals, Eur. J. Oncol. Nurs. 15 (2011) 419-27. doi:10.1016/j.ejon.2010.10.010.

[20] A. Halpert, E. Godena, Irritable bowel syndrome patients' perspectives on their relationships with healthcare providers, Scand. J. Gastroenterol. 46 (2011) 823-830. doi:10.3109/00365521.2011.574729. 
[21] D. McLaughlin, H. McKenna, J. Leslie, K. Moore, J. Robinson, Illicit drug users in Northern Ireland: perceptions and experiences of health and social care professionals., J. Psychiatr. Ment. Health Nurs. 13 (2006) 682-686. http://ovidsp.ovid.com/ovidweb.cgi?T=JS\&PAGE=reference\&D=med5\&NEWS=N\&AN=170876 70.

[22] C. Beck, Quantitative measurement of caring, J. Adv. Nurs. 30 (1999) 24-32. doi:10.1046/j.1365-2648.1999.01045.x.

[23] E. Papastavrou, G. Efstathiou, H. Tsangari, R. Suhonen, H. Leino-Kilpi, E. Patiraki, C. Karlou, Z. Balogh, A. Palese, M. Tomietto, D. Jarosova, A. Merkouris, A cross-cultural study of the concept of caring through behaviours: Patients' and nurses' perspectives in six different EU countries, J. Adv. Nurs. 68 (2012) 1026-1037. doi:10.1111/j.1365-2648.2011.05807.x.

[24] A.G. Tuckett, K. Hughes, P.J. Schluter, C. Turner, Validation of CARE-Q in residential agedcare: Rating of importance of caring behaviours from an e-cohort sub-study, J. Clin. Nurs. 18 (2009) 1501-9. doi:10.1111/j.1365-2702.2008.02723.x.

[25] Y. Chang, Y. Lin, H. Chang, C. Lin, Cancer patient and staff ratings of caring behaviors: Relationship to level of pain intensity, Cancer Nurs. 28 (2005) 331-39. doi:10.1097/00002820-200509000-00001.

[26] M. Ridd, A. Shaw, G. Lewis, C. Salisbury, The patient-doctor relationship: a synthesis of the qualitative literature on patients' perspectives, Br. J. Gen. Pract. 59 (2009) 268-75. doi:10.3399/bjgp09X420248.

[27] V. Entwistle, D. Firnigl, M. Ryan, J. Francis, P. Kinghorn, Which experiences of health care delivery matter to service users and why? A critical interpretive synthesis and conceptual map., J. Health Serv. Res. Policy. 17 (2012) 70-78. doi:10.1258/jhsrp.2011.011029.

[28] A.L. Kitson, C. Dow, J.D. Calabrese, L. Locock, A.M. Athlin, Stroke survivors' experiences of the fundamentals of care: A qualitative analysis, Int. J. Nurs. Stud. 50 (2013) 392-403. doi:10.1016/j.ijnurstu.2012.09.017.

[29] A. Kitson, A. Marshall, K. Bassett, K. Zeitz, What are the core elements of patient-centred care? A narrative review and synthesis of the literature from health policy, medicine and nursing, J. Adv. Nurs. 69 (2013) 4-15. doi:10.1111/j.1365-2648.2012.06064.x.

[30] N. King, C. Horrocks, Interviews in Qualitative Research, 1st ed., CPI Group (UK) Ltd, London, 2010.

[31] H. Arksey, L. O'Malley, Scoping studies: towards a methodological framework, Int. J. Soc. Res. Methodol. 8 (2005) 19-32. doi:10.1080/1364557032000119616.

[32] D. Levac, H. Colquhoun, K.K. O'Brien, Scoping studies: advancing the methodology., Implement. Sci. 5 (2010) 69. doi:10.1186/1748-5908-5-69.

[33] A. Booth, "Brimful of STARLITE": toward standards for reporting literature searches, J. Med. Libr. Assoc. JMLA. 94 (2006) 421-29.

[34] D. Moher, A. Liberati, J. Tetzlaff, D.G. Altman, Preferred Reporting Items for Systematic Reviews and Meta-Analyses: The PRISMA Statement, Ann. Intern. Med. 151 (2009) 264-69. doi:10.1371/journal.pmed.1000097.

[35] Critical Skills Appraisal Programme (CASP), (n.d.). http://www.casp-uk.net (accessed November 1, 2015).

[36] S. Yardley, T. Dornan, Kirkpatrick's levels and education "evidence," Med. Educ. 46 (2012) 97106. doi:10.1111/j.1365-2923.2011.04076.x. 
Table 1: Search Strategy

(a) STARLITE Summary of Search Strategy

\begin{tabular}{|l|l|l|l|}
\hline S & Sampling Strategy & Comprehensive - attempting to identify all published material \\
\hline T & Type of Study & $\begin{array}{l}\text { Any study - qualitative or quantitative, provided quantitative } \\
\text { instruments were developed by first exploring patients' experiences. }\end{array}$ \\
\hline A & Approaches & $\begin{array}{l}\text { Searching electronic databases and screening the reference lists of } \\
\text { included articles }\end{array}$ \\
\hline R & Range of Years & From inception of individual databases to February 2016 \\
\hline L & Limits & English language articles; adults \\
\hline I & Inclusion / Exclusion & See Table 2 & SCOPUS \\
\hline T & Terms Used & See text & $\begin{array}{l}\text { PYSCHinfo } \\
\text { ERIC }\end{array}$ \\
\hline E & Electronic Databases & $\begin{array}{l}\text { Ovid MEDLINE } \\
\text { Web of Science }\end{array}$ &
\end{tabular}


Table 2: Inclusion and exclusion criteria

\begin{tabular}{|l|l}
\hline Inclusion criteria & Exclusion criteria
\end{tabular}

- About caring and caring relationships

- Reporting patients' or lay-peoples' experiences

- $\quad$ Related to healthcare

- Written in English

- $\quad$ Concerning adults

- $\quad$ Could complete the sentence: "This research shows that a patient would feel cared for if (s)he experienced..."

- $\quad$ Reporting professionals' opinions and experiences rather than patients'

- Defining caring by means of quantitative data where patients had not been actively involved in the development of the data collection tool

- 'Care' as an outcome of resources, equipment, or treatment options rather than clinicians' behaviour

- Describing patients' experiences of a particular illness, not the care received

- Case studies, commentaries editorials, dissertations, conference abstracts, and research letters 


\begin{tabular}{|c|c|c|c|c|c|c|c|c|c|c|c|}
\hline \multirow[b]{2}{*}{$\begin{array}{l}\text { Resource } \\
\text { Number }\end{array}$} & \multirow[b]{2}{*}{ First author } & \multirow[b]{2}{*}{ Year } & \multirow[b]{2}{*}{ Country } & \multirow[b]{2}{*}{ Context } & \multirow[b]{2}{*}{ Discipline } & \multicolumn{3}{|c|}{ Patient Respondents } & \multirow[b]{2}{*}{$\begin{array}{c}\text { Method of } \\
\text { data collection }\end{array}$} & \multirow[b]{2}{*}{ Methodology } & \multirow[b]{2}{*}{ Aim } \\
\hline & & & & & & $\mathrm{N}$ & $\begin{array}{l}\text { Male : } \\
\text { Female }\end{array}$ & $\begin{array}{l}\text { Age } \\
\text { Range }\end{array}$ & & & \\
\hline 1 & Ahl [37] & 2012 & Sweden & $\begin{array}{l}\text { Pre-hospital } \\
\text { care }\end{array}$ & All HCPs & 20 & $8: 12$ & $34-82$ & $\begin{array}{l}\text { Semi- } \\
\text { structured } \\
\text { interviews }\end{array}$ & $\begin{array}{l}\text { Ricoeur's } \\
\text { interpretation } \\
\text { theory }\end{array}$ & $\begin{array}{l}\text { Interpret the meaning of pre-hospital } \\
\text { caring from the patient's point of view }\end{array}$ \\
\hline 2 & Attree [17] & 2001 & UK & $\begin{array}{l}\text { Acute medical } \\
\text { ward }\end{array}$ & All HCPs & 34 & $18: 16$ & 19-89 & $\begin{array}{l}\text { Semi- } \\
\text { structured } \\
\text { interviews }\end{array}$ & Grounded theory & $\begin{array}{l}\text { Explore patients' and relatives' perceptions } \\
\text { of care, via descriptions of actual } \\
\text { experiences }\end{array}$ \\
\hline 3 & $\begin{array}{l}\text { Bendapudi } \\
\text { [38] }\end{array}$ & 2006 & USA & $\begin{array}{l}14 \text { Medical } \\
\text { Specialities }\end{array}$ & Physicians & 192 & $\begin{array}{l}\text { 50:50 } \\
\text { split }\end{array}$ & $\begin{array}{l}\text { Not } \\
\text { reported }\end{array}$ & $\begin{array}{l}\text { Telephone } \\
\text { interviews }\end{array}$ & Thematic Analysis & $\begin{array}{l}\text { Develop a profile of ideal physician } \\
\text { behaviours }\end{array}$ \\
\hline 4 & Berg [39] & 1996 & Sweden & Obstetric Care & Midwives & 18 & $0: 18$ & $23-38$ & Interviews & $\begin{array}{l}\text { Interpretative } \\
\text { phenomenology }\end{array}$ & $\begin{array}{l}\text { To describe women's experience of the } \\
\text { encounter with the midwife during } \\
\text { childbirth }\end{array}$ \\
\hline 5 & Berg [40] & 2007 & Sweden & Hospital care & Nurses & 7 & $3: 4$ & $51-75$ & $\begin{array}{l}\text { Semi- } \\
\text { structured } \\
\text { interviews }\end{array}$ & $\begin{array}{l}\text { Interpretative } \\
\text { phenomenology }\end{array}$ & $\begin{array}{l}\text { Illuminate patients with long term } \\
\text { illnesses' experiences of care }\end{array}$ \\
\hline 6 & Bramley [41] & 2014 & UK & Hospital care & Nurses & 10 & $5: 5$ & $18-91$ & $\begin{array}{l}\text { Semi- } \\
\text { structured } \\
\text { interviews }\end{array}$ & $\begin{array}{l}\text { Qualitative } \\
\text { exploratory } \\
\text { description }\end{array}$ & $\begin{array}{l}\text { Understand how patients experience } \\
\text { compassion within nursing care }\end{array}$ \\
\hline 7 & Calman [42] & 2006 & UK & Hospital care & Nurses & 27 & $\begin{array}{l}\text { Not } \\
\text { reported }\end{array}$ & $20-78$ & $\begin{array}{l}\text { In depth } \\
\text { interviews }\end{array}$ & Grounded theory & $\begin{array}{l}\text { Examine what is meant by competent } \\
\text { nursing }\end{array}$ \\
\hline 8 & Canzan [43] & 2014 & Italy & $\begin{array}{l}\text { Hospital, } \\
\text { geriatric care }\end{array}$ & Nurses & 20 & $2: 18$ & $66-80$ & $\begin{array}{l}\text { Semi - } \\
\text { structured } \\
\text { interviews }\end{array}$ & $\begin{array}{l}\text { Qualitative } \\
\text { descriptive study }\end{array}$ & $\begin{array}{l}\text { Understand how older patients experience } \\
\text { nursing care }\end{array}$ \\
\hline 9 & $\begin{array}{l}\text { Cocksedge } \\
{[44]}\end{array}$ & 2013 & UK & $\begin{array}{l}\text { General } \\
\text { Practice }\end{array}$ & $\begin{array}{l}\text { Physicians } \\
\text { (General } \\
\text { Practitioners } \\
\text { [GPs[\} }\end{array}$ & 11 & $7: 4$ & $50->80$ & $\begin{array}{l}\text { Semi - } \\
\text { structured } \\
\text { interviews }\end{array}$ & $\begin{array}{l}\text { Constant } \\
\text { comparative } \\
\text { qualitative analysis }\end{array}$ & $\begin{array}{l}\text { Explore GPs' and patients' experiences of } \\
\text { using touch in consultations }\end{array}$ \\
\hline 10 & Conner [45] & 2008 & UK & Palliative care & $\begin{array}{l}\text { Physicians } \\
\text { and nurses }\end{array}$ & 10 & $\begin{array}{l}\text { Not } \\
\text { reported }\end{array}$ & $\begin{array}{l}\text { Not } \\
\text { reported }\end{array}$ & $\begin{array}{l}\text { Narrative } \\
\text { interviews }\end{array}$ & $\begin{array}{l}\text { Thematic content } \\
\text { analysis }\end{array}$ & $\begin{array}{l}\text { Explore the views of patients referred to a } \\
\text { specialist palliative care team about their } \\
\text { healthcare services }\end{array}$ \\
\hline 11 & Copeland & 2003 & USA & Primary care & Primary care & 50 & $0: 50$ & $18->55$ & Focus groups & Thematic analysis & Examine African American women's views \\
\hline
\end{tabular}




\begin{tabular}{|c|c|c|c|c|c|c|c|c|c|c|c|}
\hline & [18] & & & & providers & & & & & & $\begin{array}{l}\text { of the doctor-patient relationship, their } \\
\text { satisfaction with that relationship, their } \\
\text { knowledge of the health care system, and } \\
\text { their beliefs about what makes a good } \\
\text { doctor }\end{array}$ \\
\hline 12 & $\begin{array}{l}\text { Den Bano } \\
\text { Aledo [15] }\end{array}$ & 2014 & Spain & $\begin{array}{l}\text { Outpatient } \\
\text { physiotherapy } \\
\text { /rehabilitation } \\
\text { services }\end{array}$ & $\begin{array}{l}\text { Physio- } \\
\text { therapists }\end{array}$ & 57 & $33: 24$ & $<30->45$ & Focus groups & Thematic analysis & $\begin{array}{l}\text { Identify elements of the physiotherapist- } \\
\text { patient interaction that are considered by } \\
\text { the patient when evaluating the quality of } \\
\text { care }\end{array}$ \\
\hline 13 & Fletcher [46] & 2007 & USA & Hospital care & All HCPs & 17 & $13: 4$ & $20-81$ & Interviews & Grounded theory & $\begin{array}{l}\text { Explore what is important to patients } \\
\text { about bedside interactions with physician } \\
\text { teams }\end{array}$ \\
\hline 14 & $\begin{array}{l}\text { Greenfield } \\
{[16]}\end{array}$ & 2010 & USA & $\begin{array}{l}\text { Orthopaedics / } \\
\text { Acute care / } \\
\text { rehabilitation }\end{array}$ & $\begin{array}{l}\text { Physio- } \\
\text { therapists }\end{array}$ & 9 & $3: 6$ & $31-77$ & $\begin{array}{l}\text { Semi- } \\
\text { structured } \\
\text { interviews }\end{array}$ & Phenomenology & $\begin{array}{l}\text { Understand the essential meaning of } \\
\text { caring behaviours from patients } \\
\text { undergoing physical therapy }\end{array}$ \\
\hline 15 & Griffiths [47] & 2012 & UK & $\begin{array}{l}\text { Carers/Cancer } \\
\text { service uses/ } \\
\text { older } \\
\text { people/mens } \\
\text { health/parents } \\
\text { /HIV service } \\
\text { users }\end{array}$ & Nurses & 52 & $23: 29$ & $\begin{array}{l}\text { Not } \\
\text { reported }\end{array}$ & Focus groups & Framework analysis & $\begin{array}{l}\text { Inform curriculum development via } \\
\text { qualities patients sought in nurses }\end{array}$ \\
\hline 16 & $\begin{array}{l}\text { Halldórs- } \\
\text { dóttir [48] }\end{array}$ & 1996 & Iceland & Obstetric care & $\begin{array}{l}\text { Nurse- } \\
\text { midwives }\end{array}$ & 10 & $0: 10$ & $33-42$ & True dialogues & Phenomenology & $\begin{array}{l}\text { Clarify women's experience of caring and } \\
\text { uncaring encounters during childbirth }\end{array}$ \\
\hline 17 & Halpert [20] & 2011 & USA & $\begin{array}{l}\text { Patients with } \\
\text { Irritable Bowel } \\
\text { Syndrome }\end{array}$ & $\begin{array}{l}\text { Physicians } \\
\text { (GPs, gast- } \\
\text { roenterolo- } \\
\text { gists), nurses }\end{array}$ & 57 & $10: 47$ & $\begin{array}{l}\text { Mean }= \\
41.1 \\
(S D=14.0 \\
4)\end{array}$ & $\begin{array}{l}\text { Expressive } \\
\text { writing }\end{array}$ & $\begin{array}{l}\text { Qualitative content } \\
\text { analysis }\end{array}$ & $\begin{array}{l}\text { Examine patients' perspectives on their } \\
\text { relationships with HCPs as communicated } \\
\text { in their expressive writing about IBS }\end{array}$ \\
\hline 18 & Haugli [49] & 2004 & Norway & $\begin{array}{l}\text { Patients with } \\
\text { rheumatic } \\
\text { disease }\end{array}$ & Doctors & 26 & $4: 22$ & $20-80$ & Focus groups & $\begin{array}{l}\text { Qualitative } \\
\text { analytical processes }\end{array}$ & $\begin{array}{l}\text { Evaluate what patients with rheumatic } \\
\text { disease perceive as important in health- } \\
\text { care encounters }\end{array}$ \\
\hline 19 & $\begin{array}{l}\text { Hershberger } \\
{[50]}\end{array}$ & 2008 & USA & Fertility clinic & Nurses & 8 & $0: 8$ & $33-46$ & $\begin{array}{l}\text { Qualitative } \\
\text { descriptive } \\
\text { interviews }\end{array}$ & Phenomenology & $\begin{array}{l}\text { Describe pregnant donor oocyte recipients' } \\
\text { perceptions of the essence of nurses' } \\
\text { caring behaviour }\end{array}$ \\
\hline 20 & Hudon [51] & 2013 & Canada & Primary care & $\begin{array}{l}\text { Physicians } \\
\text { (GPs) }\end{array}$ & 30 & $13: 17$ & $35-75$ & $\begin{array}{l}\text { In-depth } \\
\text { interviews }\end{array}$ & $\begin{array}{l}\text { Qualitative } \\
\text { description }\end{array}$ & $\begin{array}{l}\text { Identify physicians' enabling attitudes and } \\
\text { behaviours from perspective of patients }\end{array}$ \\
\hline
\end{tabular}




\begin{tabular}{|c|c|c|c|c|c|c|c|c|c|c|c|}
\hline & & & & & & & & & & & with chronic diseases \\
\hline 21 & Hunt [52] & 1999 & Australia & $\begin{array}{l}\text { Intensive care } \\
\text { unit }\end{array}$ & Nurses & 12 & $\begin{array}{l}\text { Not } \\
\text { reported }\end{array}$ & $\begin{array}{l}\text { Not } \\
\text { reported }\end{array}$ & $\begin{array}{l}\text { Semi- } \\
\text { structured } \\
\text { interviews }\end{array}$ & Thematic analysis & $\begin{array}{l}\text { The cardiac surgery patients' expectations } \\
\text { and experiences of nursing care in the } \\
\text { intensive care unit }\end{array}$ \\
\hline 22 & Jannsen [53] & 2010 & $\begin{array}{l}\text { New } \\
\text { Zealand }\end{array}$ & $\begin{array}{l}\text { Community } \\
\text { hospice } \\
\text { programmes }\end{array}$ & Doctors & 13 & $\begin{array}{l}\text { Not } \\
\text { reported }\end{array}$ & $\begin{array}{l}\text { Not } \\
\text { reported }\end{array}$ & $\begin{array}{l}\text { Semi- } \\
\text { structured } \\
\text { interviews }\end{array}$ & $\begin{array}{l}\text { Interpretative } \\
\text { phenomonology }\end{array}$ & $\begin{array}{l}\text { Hear what patients approaching death had } \\
\text { to say about doctor-patient interactions } \\
\text { and care }\end{array}$ \\
\hline 23 & Jannsen [54] & 2010 & $\begin{array}{l}\text { New } \\
\text { Zealand }\end{array}$ & Hospice care & $\begin{array}{l}\text { Physicians } \\
\text { (non- } \\
\text { specialists in } \\
\text { palliative } \\
\text { care) }\end{array}$ & 13 & $5: 8$ & $\begin{array}{l}\text { Not } \\
\text { reported }\end{array}$ & $\begin{array}{l}\text { Semi - } \\
\text { structured } \\
\text { interviews }\end{array}$ & $\begin{array}{l}\text { Interpretative } \\
\text { phenomenology }\end{array}$ & $\begin{array}{l}\text { Better understand the nature of medical } \\
\text { care from the perspective of people } \\
\text { approaching the end of life }\end{array}$ \\
\hline 24 & Johnston [55] & 2006 & UK & $\begin{array}{l}\text { Acute hospital } \\
\text { / hospice }\end{array}$ & $\begin{array}{l}\text { Expert } \\
\text { palliative } \\
\text { care nurses }\end{array}$ & 22 & $\begin{array}{l}\text { Not } \\
\text { reported }\end{array}$ & $\begin{array}{l}\text { Not } \\
\text { reported }\end{array}$ & $\begin{array}{l}\text { In depth } \\
\text { interviews }\end{array}$ & Phenomenology & $\begin{array}{l}\text { Study the perceptions of patients and } \\
\text { nurses on palliative care }\end{array}$ \\
\hline 25 & $\begin{array}{l}\text { Johnston } \\
\text { Taylor [56] }\end{array}$ & 2003 & USA & Oncology & Nurses & 21 & $10: 11$ & $\begin{array}{l}\text { Not } \\
\text { reported }\end{array}$ & $\begin{array}{l}\text { Semi - } \\
\text { structured } \\
\text { interviews }\end{array}$ & $\begin{array}{l}\text { Miles and } \\
\text { Huberman's } \\
\text { approach to } \\
\text { analysis }\end{array}$ & $\begin{array}{l}\text { Determine what patients with cancer } \\
\text { expect from nurses with regard to having } \\
\text { their spiritual needs addressed }\end{array}$ \\
\hline 26 & Kendall [57] & 2006 & UK & Primary care & $\begin{array}{l}\text { Physicians } \\
\text { (GPs) }\end{array}$ & 14 & $7: 7$ & $35-70$ & $\begin{array}{l}\text { Discussion } \\
\text { groups }\end{array}$ & Action research & $\begin{array}{l}\text { Involve patients with cancer and their } \\
\text { carers in designing a framework for } \\
\text { providing effective cancer care in primary } \\
\text { care }\end{array}$ \\
\hline 27 & Kvale [58] & 2010 & Norway & $\begin{array}{l}\text { Oncology } \\
\text { ward, regional } \\
\text { hospital }\end{array}$ & Nurses & 20 & $10: 10$ & $25-80$ & Interviews & Phenomenology & $\begin{array}{l}\text { Clarify how and why patients' perceptions } \\
\text { of nurses' knowledge about cancer and it } \\
\text { treatments relates to quality care }\end{array}$ \\
\hline 28 & Lafferty [19] & 2011 & UK & $\begin{array}{l}\text { Oncology } \\
\text { ward }\end{array}$ & All HCPs & 47 & $0: 47$ & $\begin{array}{l}\text { Not } \\
\text { reported }\end{array}$ & Focus groups & Thematic analysis & $\begin{array}{l}\text { Explore the concept of continuity of care } \\
\text { from the perspective of women diagnosed } \\
\text { with breast cancer }\end{array}$ \\
\hline 29 & Laird [59] & 2015 & UK & $\begin{array}{l}\text { Variety of } \\
\text { hospital wards }\end{array}$ & Nurses & 26 & $7: 19$ & $\begin{array}{l}\text { Not } \\
\text { reported }\end{array}$ & $\begin{array}{l}\text { Narrative } \\
\text { interviews }\end{array}$ & Structural analysis & $\begin{array}{l}\text { Illuminate the experiences of patients of } \\
\text { care received in hospital wards during an } \\
\text { intervention programme to develop } \\
\text { patient centred practice }\end{array}$ \\
\hline
\end{tabular}




\begin{tabular}{|c|c|c|c|c|c|c|c|c|c|c|c|}
\hline 30 & Larabee [60] & 2001 & USA & $\begin{array}{l}\text { Medical/surgic } \\
\text { al ward }\end{array}$ & Nurses & 199 & $107: 92$ & Mean: 39 & $\begin{array}{l}\text { Written } \\
\text { comments }\end{array}$ & $\begin{array}{l}\text { Qualitative } \\
\text { descriptive study }\end{array}$ & $\begin{array}{l}\text { Identify dimensions of nursing care quality } \\
\text { from patients perspective }\end{array}$ \\
\hline 31 & Levine [61] & 2012 & USA & $\begin{array}{l}\text { Ambulatory } \\
\text { care }\end{array}$ & $\begin{array}{l}\text { Physicians, } \\
\text { nurse } \\
\text { practitioners } \\
\text { \& physician } \\
\text { assistants }\end{array}$ & 168 & $50: 118$ & $21-70+$ & $\begin{array}{l}\text { Telephone } \\
\text { interviews }\end{array}$ & $\begin{array}{l}\text { Critical incident } \\
\text { technique }\end{array}$ & $\begin{array}{l}\text { Determine (i) how patients and clinicians } \\
\text { define quality care, (ii) in what ways } \\
\text { patients' and physicians' definitions differ } \\
\text { and (iii) whether patients' definitions vary } \\
\text { by ethnicity }\end{array}$ \\
\hline 32 & $\begin{array}{l}\text { Lundgren } \\
\text { [62] }\end{array}$ & 2007 & Norway & Obstetrics & Midwifes & 96 & $0: 96$ & $\begin{array}{l}\text { Not } \\
\text { reported }\end{array}$ & $\begin{array}{l}\text { Analysis of } \\
\text { transcripts }\end{array}$ & $\begin{array}{l}\text { Qualitative } \\
\text { secondary analysis }\end{array}$ & $\begin{array}{l}\text { Clarify central concepts of the woman- } \\
\text { midwife relationship }\end{array}$ \\
\hline 33 & $\begin{array}{l}\text { McLaughlin } \\
\text { [63] }\end{array}$ & 2000 & $\begin{array}{l}\text { Northern } \\
\text { Ireland }\end{array}$ & $\begin{array}{l}\text { Illicit drug } \\
\text { users }\end{array}$ & All HCPs & 20 & $13: 7$ & $18-56$ & Focus groups & Thematic analysis & $\begin{array}{l}\text { Clarify how illicit drug users experience } \\
\text { being cared for }\end{array}$ \\
\hline 34 & McLean [64] & 2013 & Australia & Obstetrics & All HCPs & 6 & $0: 6$ & $31-41$ & $\begin{array}{l}\text { Semi- } \\
\text { structured } \\
\text { interviews }\end{array}$ & Thematic analysis & $\begin{array}{l}\text { Clarify how women who have miscarried } \\
\text { experience being cared for in hospital }\end{array}$ \\
\hline 35 & Mok [65] & 2003 & China & Palliative care & Nurses & 10 & $6: 4$ & $40-78$ & $\begin{array}{l}\text { Open ended, } \\
\text { unstructured } \\
\text { interviews }\end{array}$ & Phenomenology & $\begin{array}{l}\text { Explore aspects of nurse patient } \\
\text { relationships in the context of palliative } \\
\text { care }\end{array}$ \\
\hline 36 & Nolan [66] & 2005 & UK & $\begin{array}{l}\text { General } \\
\text { practice }\end{array}$ & $\begin{array}{l}\text { Physicians } \\
\text { (GPs) }\end{array}$ & 60 & $23: 37$ & $24-67$ & $\begin{array}{l}\text { Semi- } \\
\text { structured } \\
\text { interviews }\end{array}$ & Thematic analysis & $\begin{array}{l}\text { Aspects of the relationship between } \\
\text { doctors and depressed patients that } \\
\text { enhance satisfaction with primary care }\end{array}$ \\
\hline 37 & Pejner [67] & 2015 & Sweden & Geriatric ward & Nurses & 18 & $6: 12$ & $80-96$ & $\begin{array}{l}\text { Semi- } \\
\text { structured } \\
\text { interviews }\end{array}$ & Grounded Theory & $\begin{array}{l}\text { Clarify processes that contribute to } \\
\text { emotional support }\end{array}$ \\
\hline 38 & Quirk [68] & 2008 & USA & Community & Physicians & 46 & $16: 30$ & $\begin{array}{l}\text { Not } \\
\text { reported }\end{array}$ & $\begin{array}{l}\text { 'Think aloud' } \\
\text { exercises, } \\
\text { video rating \& } \\
\text { focus group } \\
\text { discussions }\end{array}$ & $\begin{array}{l}\text { Cognitive scale } \\
\text { development }\end{array}$ & $\begin{array}{l}\text { Define caring behaviours, to create a } \\
\text { 'patient centred' caring attitude checklist }\end{array}$ \\
\hline 39 & Radwin [69] & 2005 & USA & Oncology & Nurses & 22 & 7:15 & $27-82$ & $\begin{array}{l}\text { Semi- } \\
\text { structured } \\
\text { interviews }\end{array}$ & Grounded theory & $\begin{array}{l}\text { Clarify how patients perceive the attributes } \\
\text { and outcomes of quality nursing care }\end{array}$ \\
\hline 40 & $\begin{array}{l}\text { Richardson } \\
{[70]}\end{array}$ & 2002 & UK & $\begin{array}{l}\text { Community } \\
\text { hospice care }\end{array}$ & Nurses & 12 & $5: 7$ & $35-80$ & $\begin{array}{l}\text { Semi- } \\
\text { structured } \\
\text { interviews }\end{array}$ & Phenomenology & $\begin{array}{l}\text { Identify and describe palliative patients' } \\
\text { perceptions of factors within the } \\
\text { interaction with palliative care nurse that } \\
\text { enhance feelings of health and wellbeing }\end{array}$ \\
\hline
\end{tabular}




\begin{tabular}{|c|l|l|l|l|l|l|l|l|l|l|l|}
\hline 41 & Rush [71] & 2006 & UK & $\begin{array}{l}\text { Community } \\
\text { care }\end{array}$ & Nurses & 96 & $\begin{array}{l}\text { Not } \\
\text { reported }\end{array}$ & $\begin{array}{l}\text { Not } \\
\text { reported }\end{array}$ & Focus groups & Phenomenology & Identify what makes a good nurse \\
\hline 42 & Schmidt [72] & 2003 & USA & $\begin{array}{l}\text { Academic } \\
\text { medical centre }\end{array}$ & Nurses & 8 & $3: 5$ & $\begin{array}{l}\text { Mean: } \\
55.85\end{array}$ & Interviews & Grounded theory & $\begin{array}{l}\text { Discover patients' experiences of care in } \\
\text { hospital settings }\end{array}$ \\
\hline 43 & Schroder [73] & 2006 & Sweden & $\begin{array}{l}\text { Psychiatric } \\
\text { care (in- and } \\
\text { out-patient) }\end{array}$ & $\begin{array}{l}\text { Nurses and } \\
\text { physicians }\end{array}$ & 20 & $\begin{array}{l}\text { Not } \\
\text { reported }\end{array}$ & $24-64$ & $\begin{array}{l}\text { Semi } \\
\text { structured } \\
\text { interviews }\end{array}$ & $\begin{array}{l}\text { Phenomenograpic } \\
\text { approach }\end{array}$ & $\begin{array}{l}\text { How patients perceive the concept of } \\
\text { quality of care in the psychiatric setting }\end{array}$ \\
\hline 44 & Ziebland [74] & 2011 & UK & $\begin{array}{l}\text { Lymphoma } \\
\text { care (in NHS) }\end{array}$ & $\begin{array}{l}\text { Physicians } \\
\text { and nurses }\end{array}$ & 41 & $19: 22$ & $27-84$ & $\begin{array}{l}\text { In depth } \\
\text { interviews }\end{array}$ & $\begin{array}{l}\text { Thematic analysis - } \\
\text { constant } \\
\text { comparison and } \\
\text { axial coding. } \\
\text { Narrative analysis }\end{array}$ \\
\hline
\end{tabular}




\begin{tabular}{|c|c|c|c|c|c|}
\hline $\begin{array}{l}\text { Theme } \\
\text { (Patients } \\
\text { experienced ...) }\end{array}$ & Description & Sub-theme & Description & Illustrative quotations & Resource Number \\
\hline Competence & $\begin{array}{l}\text { Patients experienced } \\
\text { caring when HCPs applied } \\
\text { knowledge and skills to } \\
\text { meet patients' needs } \\
\text { proficiently. }\end{array}$ & & & $\begin{array}{l}\text { I just want them to be really competent } \\
\text { and really good at what they do - and that } \\
\text { makes me feel good. [50] }\end{array}$ & $\begin{array}{l}1,3,5,7,8,12,15,16 \\
17,20,23,24,27,30 \\
31,34,39,41\end{array}$ \\
\hline $\begin{array}{l}\text { Positive } \\
\text { attitudes }\end{array}$ & $\begin{array}{l}\text { Patients experienced } \\
\text { caring when HCPs } \\
\text { displayed positive } \\
\text { attitudes; for example, } \\
\text { sincerity, kindness, and } \\
\text { respect }\end{array}$ & & & $\begin{array}{l}\text { You could tell from his attitude that he was } \\
\text { very strong, very positive, very confident, } \\
\text { that he could help me. His confidence } \\
\text { made me feel relaxed. [38] }\end{array}$ & $\begin{array}{l}2,3,6,8,13,15,16,19 \\
21,22,29,30,34,37 \\
38,39,40,41,44\end{array}$ \\
\hline \multirow[t]{4}{*}{$\begin{array}{l}\text { Effective } \\
\text { communication }\end{array}$} & \multirow[t]{4}{*}{$\begin{array}{l}\text { Patients experienced } \\
\text { caring when HCPs } \\
\text { effectively communicated } \\
\text { with them. }\end{array}$} & Talking & $\begin{array}{l}\text { Patients experienced caring when } \\
\text { HCPs choose their words } \\
\text { carefully, made helpful } \\
\text { comments and answered } \\
\text { questions. }\end{array}$ & $\begin{array}{l}\text { [Doctors should] ...tell everything there is } \\
\text { to know, not just what doctors think you } \\
\text { should know. [42] }\end{array}$ & $\begin{array}{l}7,10,14,22,25,31,38 \\
41\end{array}$ \\
\hline & & Listening & $\begin{array}{l}\text { Patients experienced caring when } \\
\text { HCPs spent time listening to } \\
\text { them. }\end{array}$ & $\begin{array}{l}\text { There is one oncologist who is absolutely } \\
\text { splendid ... very willing to listen to what I } \\
\text { wanted in the way of therapy, how I felt...I } \\
\text { can't speak too highly of him. [53] }\end{array}$ & $\begin{array}{l}10,12,14,15,17,24 \\
25,31,36,38,41,44\end{array}$ \\
\hline & & $\begin{array}{l}\text { Non-Verbal } \\
\text { Behaviour }\end{array}$ & $\begin{array}{l}\text { Behaviours, such as appropriate } \\
\text { body language and eye contact } \\
\text { were experienced as caring. }\end{array}$ & A smile does a lot. [56] & $9,15,19,20,22,38,41$ \\
\hline & & \begin{tabular}{|l|} 
Sharing \\
knowledge
\end{tabular} & $\begin{array}{l}\text { Communication which led to the } \\
\text { effective sharing of knowledge } \\
\text { was experienced as caring. }\end{array}$ & $\begin{array}{l}\text { They always explain what the medication is } \\
\text { and what it's for, and that's the main thing. } \\
\text { [69] }\end{array}$ & $\begin{array}{l}2,10,13,14,17,18,19 \\
20,26,27,34,36,40 \\
41,42,44\end{array}$ \\
\hline Relationships & $\begin{array}{l}\text { Patients experienced } \\
\frac{\text { caring with meaningful }}{\text { relationships that made }}\end{array}$ & $\begin{array}{l}\text { Trust and } \\
\text { respect }\end{array}$ & $\begin{array}{l}\text { Being valued, with mutual trust } \\
\text { and respect was experienced as } \\
\text { caring. }\end{array}$ & $\begin{array}{l}\text { With a trusting relationship, as patient I } \\
\text { could tell her everything I need ... The } \\
\text { nurse was not only a healthcare }\end{array}$ & $\begin{array}{l}4,6,11,16,20,31,32 \\
35,38\end{array}$ \\
\hline
\end{tabular}




\begin{tabular}{|c|c|c|c|c|c|}
\hline & \multirow[t]{2}{*}{$\begin{array}{l}\text { patients feel comfortable } \\
\text { and at ease. }\end{array}$} & & & $\begin{array}{l}\text { professional, she was also a good friend, } \\
\text { part of the family. [65] }\end{array}$ & \\
\hline & & $\begin{array}{l}\text { Patients as } \\
\text { individuals }\end{array}$ & $\begin{array}{l}\text { Being treated as an individual, } \\
\text { with account being taken of } \\
\text { patients personal values was } \\
\text { experienced as caring. }\end{array}$ & $\begin{array}{l}\text { The oncologist said, "so tell me about } \\
\text { yourself" . . .I was so stunned because } \\
\text { nobody had ever said that. . .[usually] } \\
\text { you're just a melanoma or a bunch of } \\
\text { symptoms. [69] }\end{array}$ & $\begin{array}{l}1,2,4,6,8,10,14,15 \\
18,20,21,23,24,30 \\
32,35,39,43\end{array}$ \\
\hline \multirow[t]{3}{*}{$\begin{array}{l}\text { Being helped to } \\
\text { navigate clinical } \\
\text { services }\end{array}$} & \multirow[t]{3}{*}{$\begin{array}{l}\text { Caring was experiencing } \\
\text { HCPs as genuinely wanting } \\
\text { to help, being supportive, } \\
\text { guiding and encouraging. }\end{array}$} & $\begin{array}{l}\frac{\text { Caring was }}{\text { internally }} \\
\text { motivated }\end{array}$ & $\begin{array}{l}\text { Caring was experiencing HCPs as } \\
\text { genuinely wanting to help; being } \\
\text { motivated by a genuine desire } \\
\text { rather than status or pay. }\end{array}$ & $\begin{array}{l}\text { That's the difference, the real difference - } \\
\text { we get the feeling that they really care [70] }\end{array}$ & $\begin{array}{l}7,10,11,13,14,16,18 \\
20,22,25,29,35,38 \\
43\end{array}$ \\
\hline & & $\begin{array}{l}\text { Caring was } \\
\text { continuing }\end{array}$ & $\begin{array}{l}\text { Continuity of care was } \\
\text { experienced as caring. Temporal } \\
\text { relationships fostered trust. }\end{array}$ & $\begin{array}{l}\text { Familiarity, I want him to remember me } \\
\text { and what my problem was the last time I } \\
\text { was there so we can pick up from that and } \\
\text { keep on going [18] }\end{array}$ & $\begin{array}{l}5,9,11,20,25,28,36 \\
44\end{array}$ \\
\hline & & $\begin{array}{l}\text { Caring } \\
\frac{\text { included }}{\text { patients }}\end{array}$ & $\begin{array}{l}\text { Patients' experienced caring } \\
\text { when HCPs involved patients in } \\
\text { their care. }\end{array}$ & $\begin{array}{l}\text { My GP. . . is absolutely fantastic. She says to } \\
\text { me "this is what I think, what do you think? } \\
\text { We can do this or this, what do you think?" } \\
{[69]}\end{array}$ & $\begin{array}{l}2,4,9,20,21,22,23,26 \\
29,32,39,42,43\end{array}$ \\
\hline $\begin{array}{l}\text { Emotional } \\
\text { engagement }\end{array}$ & $\begin{array}{l}\text { Caring was knowing } \\
\text { HCPs were emotionally } \\
\text { engaged, accessible, } \\
\text { and easily contactable. }\end{array}$ & & & $\begin{array}{l}\text { I didn't want them to go, to leave me. I } \\
\text { knew that it was a safe place that I came to } \\
\text { but the ambulance personnel gave me a } \\
\text { sense of security that I know I would not } \\
\text { get there [at the emergency ward]. In the } \\
\text { emergency ward I have to ask for } \\
\text { everything, no one asks me, no one sees } \\
\text { anything. The only thing they give me is a } \\
\text { button to push if I want something. [37] }\end{array}$ & $\begin{array}{l}1,2,6,8 \\
13,14,18,19,20,22 \\
23,24,26,28,30,32 \\
35,37,38,40,4243\end{array}$ \\
\hline
\end{tabular}


Figure 1: PRISMA 2009 Flow Diagram
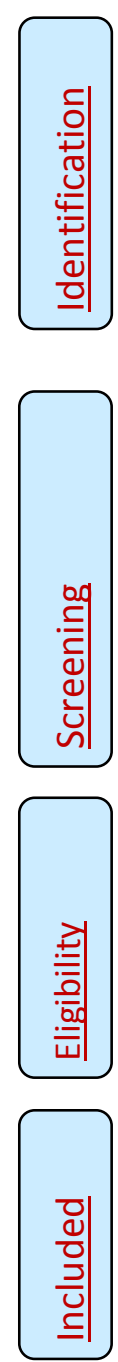

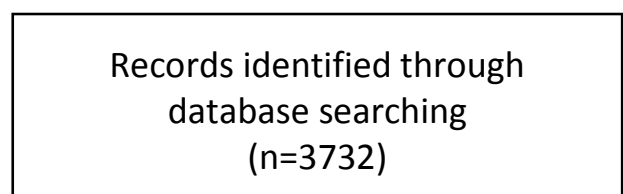

$(n=3732)$

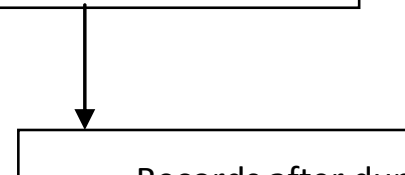

Records after duplicates removed

$(n=3220)$

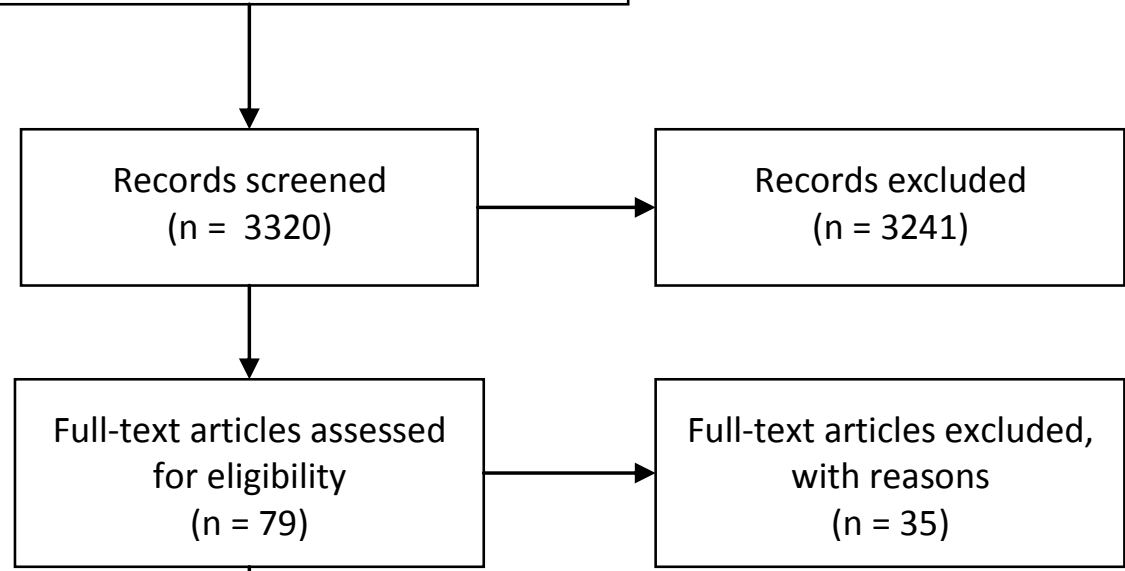

Studies included in qualitative synthesis

$$
(n=44)
$$

Additional records identified through other sources $(n=7)$ $(n=3241)$ 